Relations industrielles

Industrial Relations

\title{
David A. Peach and Paul Bergman, The Practice of Labour
}

Relations: Third Edition

\section{Norman A. Solomon}

Volume 46, numéro 3, 1991

URI : https://id.erudit.org/iderudit/050705ar

DOI : https://doi.org/10.7202/050705ar

Aller au sommaire du numéro

Éditeur(s)

Département des relations industrielles de l'Université Laval

ISSN

0034-379X (imprimé)

1703-8138 (numérique)

Découvrir la revue

Citer ce compte rendu

Solomon, N. A. (1991). Compte rendu de [David A. Peach and Paul Bergman, The Practice of Labour Relations: Third Edition]. Relations industrielles / Industrial Relations, 46(3), 667-668. https://doi.org/10.7202/050705ar

Tous droits réservés (C Département des relations industrielles de l'Université Laval, 1991
Ce document est protégé par la loi sur le droit d'auteur. L'utilisation des services d'Érudit (y compris la reproduction) est assujettie à sa politique d'utilisation que vous pouvez consulter en ligne.

https://apropos.erudit.org/fr/usagers/politique-dutilisation/ 
productivity and supervision. Both plant managers and the union officials indicated that cooperative programs usually had modest improvements rather than large improvements. Large improvements were associated with considerable commitment to the program and effort, such as frequent meetings of problem solving teams.

The study also showed that union leaders took pride in cooperative programs run in their plants. Cooke argued that more must be done to enlist union effort in running these programs. The unions had as much concern with saving manufacturing plants as did the corporations.

The message for Canadians is quite clear in terms of what it takes to compete with American plants. Greater effort must be made to promote labor-management programs at the plant level. These local efforts need to be supported by corporate strategy, national and international unions and government agencies. This book is highly recommended to leadership in government, industry and unions in order to become more effective in supporting labormanagement cooperation in Canadian manufacturing plants.

Bernard PORTIS

\section{University of Western Ontario}

The Practice of Labour Relations: Third Edition, by David A. Peach and Paul Bergman, Scarborough, Ont., McGraw Hill Ryerson, 1990, 437 p., ISBN 0-07-549936-3

Peach and Bergman have produced an excellent volume that should be seriously considered as a supplementary text for both introductory and advanced university and college courses in Canadian Industrial Relations. The outstanding feature of this text is its thirty-seven realistic, focussed and well written cases (several of which have not appeared in previous editions). The cases are suitable for classroom discussion and for role playing exercises by students.

The Practice of Industrial Relations is divided into six chapters each dealing with the following areas: an introduction to labour relations; the history of industrial relations in Canada; the organizing challenge; the negotiation challenge; the grievance challenge; and managing in a dynamic labour relations environment. The cases are appended to the various chapters. To the authors credit the cases address both traditional industrial relations concerns as well as more topical issues. Thus the chapters on organizing, negotiations and grievance handling include a number of excellent cases. In addition the chapter on managing in a dynamic labour relations environment includes cases that deal with: incentive plans; pay equity; job enrichment; and employee participation programs.

The classroom teacher should find the concise Instructors Manual very useful. The Manual has important 'tips' on how to teach cases and offers key points concerning each case. The Manual is also helpful in explaining how to use the Cashford Container case as a negotiation simulation for students. The inclusion of a scoring mechanism to use in grading, however, would have made this case even more valuable.

The main drawback of the text is the lack of scholarly detail in the otherwise well written narrative. For example, more of the narrative could be devoted to such important areas as the impact of the Charter of Rights and Freedoms on industrial relations. Also, many of the references used in the book should be updated. Thus the example given of union-management collusion is cited out of a U.S. text published in 1960; surely more recent examples (and Canadian ones at that!) are available. 
In fairness, the authors do state at the outset that the book is not meant to be exhaustive and the above criticisms must be viewed in that light. Thus despite the concerns expressed above I believe that the text has an important part to play in the teaching of Canadian Industrial Relations. Clearly, The Practice of Labour Relations: Third Edition belongs on the book shelf of every teacher and student of the subject.

Norman A. SOLOMON

University of Windsor

Does Training Work for Displaced Workers? A Survey of Existing Evidence, by Duane E. Leigh, Kalamazoo, MI, W.E. Upjohn Institute for Employment Research, 1990, 120 p., ISBN 0-88099-094-5

Back to Work: Testing Reemployment Services for Displaced Workers, by Howard S. Bloom, Kalamazoo, MI, W.E. Upjohn Institute for Employment Research, 1990, 180 p., ISBN 0-88099-098-8

Voici deux contributions additionnelles à la littérature déjà volumineuse portant sur l'expérience en termes de marché du travail de personnes victimes de licenciement collectif. Ces deux publications visent essentiellement à évaluer l'efficacité relative de deux programmes de main-d'oeuvre utilisés en contexte de licenciement: la formation professionnelle et les services de placement.

Les programmes publics de formation professionnelle ont un double rôle: d'abord, réduire les coûts sociaux et privés associés aux délais inutiles dans le processus de réemploi et ensuite assister au placement du capital humain perdu à l'occasion d'un licenciement.

Leigh tente ici de répondre à quatre questions de politique publique eu égard à l'efficacité de programmes de formation professionnelle pour accélérer le réemploi de personnes victimes de licenciement.

1. Certaines formes de formation professionnelle fonctionnent-elles mieux que d'autres?

2. Certains groupes de personnes bénéficient-ils plus que d'autres de la formation professionnelle?

3. Dans la mesure où la formation professionnelle améliore les chances de réemploi, le fait-elle en augmentant les taux de salaire post-formation ou en réduisant la durée du chômage?

4. Se référant plus spécifiquement au recyclage, comment déterminer dans quel domaine former les personnes visées?

Pour répondre à ces questions, l'auteur présente d'abord une vue d'ensemble des évaluations existentes de programmes fédéraux découlant du Comprehensive Employment and Training Act (CETA) (chapitre 2). Le chapitre 3 est, à plusieurs égards, le coeur de cette monographie. L'auteur y examine en détail la masse imposante de données quantitatives générées par quatre projets financés par le gouvernement fédéral américain durant les années 80 . Ces projets sont: le Downriver Program, le Buffalo Program of the Dislocated Worker Demonstration Project, le Texas Worker Adjustment Demonstration et le New Jersey Unemployment Insurance Re-employment Demonstration Project. 